\title{
Implementasi Perizinan Penanaman Modal di Kota Mataram
}

\author{
Ali Kurnia Widi \\ Notary Magister, Postgraduate Program, University of Mataran \\ alikurniawidi@gmail.com
}

Submitted: 2017-10-14; Reviewed: 2018-03-12; Accepted: 2018-04-30

\begin{abstract}
This study aims at investigating the investment licensing activity in Mataram city, a potential place for the investors to do investment. It is due to the large number of businessmen making their investment license in the mentioned city. Not all of the investment license is well and smoothly processed by the One-door Integrated Services of Investment Coordinating Board of Mataram city, however. It is because of some constrains in the investment licensing services. The present study, thus, aims to explain such constrains and the way the government of Mataram uses to have the businessmen understand about the importance of making investment license on their business legality. This study is expected to be used as reference and to be beneficial of the development of the related field. It is also hoped to contribute to the understanding about the implementation of licensing activity. The method of this study is normative empirical method. Primary and secondary data are the source of the data used in this study. The result of this study explains about the implementation of the investment licensing activity, the classification of license according to the types of business, the constrains in the investment licensing services (e.g. the assumption of businessmen about the existence of the technical coordinator team making the bureaucracy take too long, the pander activity, the limitation of facilities, and the mutation of functionary leading to the making of different policies), and the government's effort in getting the businessmen interested in making the legality of their business such as the launching of Sehari Pasti Jadi (One-day Service) program and of Izin Paket (Permit Package) program, and the making of the Standar Operasional Pelayanan (Standard Operating Services).
\end{abstract}

Keywords: Investment; Implementation; Liscensing; Service

\section{PENDAHULUAN}

Dalam rangka mewujudkan masyarakat adil, makmur dan sejahtera berdasarkan Pancasila dan Undang-Undang Dasar Negara Republik Indonesia Tahun 1945 diperlukan pembangunan ekonomi nasional yang berkelanjutan dengan berlandaskan demokrasi ekonomi untuk mencapai tujuan negara. Dalam rangka mempercepat pembangunan ekonomi nasional dalam mewujudkan kedaulatan politik dan ekonomi Indonesia diperlukan peningkatan kegiatan penanaman modal untuk mengolah potensi ekonomi menjadi kekuatan ekonomi riil dengan menggunakan modal yang berasal dari 
dalam negeri dan modal luar negeri.

Sejak diberlakukanya Undang-Undang Nomor 1 Tahun 1967 tentang Penanaman Modal Asing dan Undang-Undang Nomor 6 Tahun 1968 tentang Penanaman Modal Dalam Negeri, iklim penanaman modal di Indonesia relatif berkembang pesat. Pertumbuhan penanaman modal tersebut terus berlangsung sampai tahun 1996 seiring dengan berbagai kebijakan liberalisme di bidang keuangan dan perdagangan yang dikeluarkan oleh Pemerintah Indonesia. Namun pertumbuhan penanaman modal tersebut mengalami kemerosotan yang sangat tajam dan berujung dengan terjadinya krisis ekonomi pada penghujung tahun 1997. Bahkan permasalahan tersebut berlangsung sampai tahun 2007.

Undang-Undang Nomor 25 Tahun 2007 tentang Penanaman Modal sebagai dasar hukum utama pelaksanaan penanaman modal di Indonesia dan peraturan pelaksananya dengan cakupan materinya juga memberikan berbagai insentif berupa, pelayanan, fasilitas, kemudahan dan jaminan investor.

Dengan demikian adanya perbaikan dan penyempurnaan kebijakan di bidang penanaman modal pada akhirnya diharapkan dapat menciptakan kepastian hukum sehingga dapat menciptakan iklim berusaha yang lebih aman dan kondusif sehingga mampu menarik investor dalam berinvestasi.

Kebijakan desentralisasi dan otonomi daerah diharapkan mampu mewujudkan tatanan sistem pemerintahan daerah yang lebih demokratis, mempercepat

\footnotetext{
${ }^{1}$ Ermanto Fahamsyah, Hukum Penanaman Modal, Pengaturan, Pembatasan, Pengaruh Budaya Hukum dan Praktik Penanaman Modal Indonesia, Yogyakarta: LaksBang PRESSindo, 2015, hlm. 90.
}

tercapainya kesejahteraan dan kemakmuran rakyat. ${ }^{1}$ Dalam kegiatan penanaman modal tentunya sangat diperlukan peran dari pelayanan publik yang merupakan lembaga negara yang diberi kewenangan untuk mengurus kegiatan proses perizinan seperti yang telah diatur melalui Peraturan Pemerintah Nomor 38 Tahun 2007 tentang Pembagian Urusan Pemerintah Antara Pemerintah Daerah Provinsi dan Pemerintah Daerah Kabupaten/Kota. Tentunya dalam implementasi perizinan untuk kepentingan kegiatan penanaman modal perlu adanya pembenahan melalui keterbukaan dan kemudahan prosedur, penetapan tarif yang jelas dan terjangkau oleh masyarakat, profesionalitas aparatur dalam pelayanan serta tersedianya tempat pengaduan dan keluhan masyarakat serta tersedianya sistem pengawasan terhadap pelaksanaan prosedur. $^{2}$

Dengan adanya standarisasi pelayanan publik dalam pelayanan berupa pemberian pelayan perizinan penanaman modal tentu saja akan diperoleh sistem pelayanan yang baku dan berkepastian, sehingga para investor dapat mengukur tingkat pelayanan yang diberikan oleh penyelenggara kegiatan pelayanan publik, di sinilah diperlukan peranan dan fungsi kelembagaan pelayanan perizinan, khususnya komitmen dalam pelaksanaan kegiatan penanaman modal di daerah guna mengatur dan menentukan suatu standarisasi pelayanan perizinan agar diperoleh kepastian hukum dalam pemberian pelayanan yang baik, sehingga pelaku penanaman modal dapat

2 Adrian Sutedi, Hukum Perizinan Dalam Sektor Pelayanan Publik, Cetakan Ketiga, Jakarta: Sinar Grafika 2015, hlm. 3 
menyalurkan modal usahanya dengan lancar dan terukur.

Besarnya harapan dari masyarakat dan para investor terkait Lembaga Pelayan Publik sebagai pihak yang dapat mengimplementasikan kegiatan penanaman modal seperti yang sudah di amanatkan oleh Undang-Undang Nomor 25 Tahun 2007 tentang Penanaman Modal dan Undang-Undang Nomor 25 Tahun 2009 Tentang Pelayanan Publik dapat terealisasi dengan baik. Aparatur hukum baik tingkat pusat ataupun tingkat daerah dalam rangka memacu kegiatan penanaman modal guna mencapai tujuan pertumbuhan ekonomi bangsa harus dapat menciptakan iklim penanaman modal yang kondusif, jaminan keamanan dan kepastian hukum sehingga diharapkan dapat meningkatkan nilai dan mutu seperti menyederhanakan proses perizinan penanaman modal, memberikan insentif bagi penanaman modal hingga mampu mendorong pertumbuhan ekonomi.

Budaya hukum harus dibangun dengan baik dengan meningkatkan kesadaran hukum bagi semua lapisan masyarakat, khususnya aparatur penyelenggara pelayanan publik sehingga mempunyai kualitas yang baik, dengan budaya hukum yang baik maka akan tercipta suatu kepastian hukum bagi para investor tersebut.

Dengan semakin berkembangnya tingkat ekonomi dalam kehidupan bermasyarakat di Kota Mataram, dan strategisnya lokasi dalam kegiatan investasi penanaman modal yang merupakan jalur akses kegiatan investasi yang menjanjikan, sehingga memungkinkan sekali akan timbul banyaknya kegiatan penanaman modal di
Kota Mataram. Hal ini terbukti dengan masuknya investasi pada tahun 2015 sampai 2017 di Kota Mataram, dari kegiatan investasi tersebut telah berhasil menyerap tenaga kerja sekitar 30.749 (tiga puluh ribu tujuh ratus empat puluh sembilan karyawan) dengan nilai total investasi antara tahun 2014-2017 berhasil menggelontorkan total dana 15,536 $\mathrm{T}$ (Lima belas koma lima ratus tiga puluh enam triliun rupiah).

Tentunya keberhasilan tersebut tidak lepas dari peran serta Dinas Penanaman Modal Pelayanan Terpadu Satu Pintu Kota Mataram merupakan kantor pelayanan publik yang memproses perizinan sebagai lembaga yang merumuskan prosedur persyaratan waktu dan biaya izin penanaman modal berdasarkan Peraturan Kepala Badan Koordinasi Penanaman Modal RI Nomor 6 Tahun 2016 tentang Perubahan atas Peraturan Kepala BKPM Nomor 14 Tahun 2015 tentang Pedoman Tata Cara Izin Prinsip Penanaman Modal. Sebagai lembaga penyelenggara kegiatan perizinanan tentunya mempunyai banyak sekali kendala dan hambatan dalam melaksanakan kegiatan perizinan.

Berdasarkan data di atas penulisan ini mengkaji tentang kegiatan yang lebih memfokuskan pada kajian kegiatan implementasi aturan hukum penanaman modal dan implementasi undang-undang pelayanan publik di Kota Mataram serta mengkaji tentang efektifitas ketentuan aturan hukum tersebut dalam kehidupan masyarakat, membahas mengenai kendalakendala yang menghambat tentang implementasi perizinan yang diakibatkan dari adanya kesenjangan Dass Sollen dan Dass Sein dalam kegiatan penanaman modal di Kota Mataram, memunculkan 
program pelayanan perizinan yang dapat digunakan untuk mempermudah kegiatan perizinan di Kota Mataram, dengan alasan di atas maka penulis terdorong untuk melakukan kajian penelitian yang mendalam tentang kegiatan penanaman modal dalam bentuk tesis tentang Implementasi Perizinan Penanaman Modal di Kota Mataram dengan studi di Dinas Penanaman Modal Pelayanan Terpadu Satu Pintu Kota Mataram.

Berdasarkan uraian dari latar belakang di atas maka penulis mengambil dua rumusan masalah dalam penelitian ini antara lain:

a. Bagaimana implementasi penanaman modal di Kota Mataram?

b. Apa kendala dalam pelaksanaan perizinan penanaman modal di Kota Mataram?

c. Upaya Dinas Penanaman Modal Pelayanan Terpadu satu Pintu Kota Mataram dalam melakukan program guna mempermudah proses pelayanan perizinan?

Penelitian ini bertujuan untuk mengetahui bagaimana pelaksanaan perizinan penanaman modal di Kota Mataram, untuk mengetahui kendalakendala perizinan penanaman modal di Kota Mataram dan untuk mengetahui bagaimana cara yang dilakukan oleh pemerintah dalam rangka meningkatkan kesadaran masyarakat terkait perizinan penanaman modal.

Sedangkan manfaat penelitian ini adalah Manfaat teoritis diharapkan agar kajian penelitian ini nantinya dapat memberikan sumbangan pemikiran dan kontribusi bagi pengembangan ilmu pada umumnya dan khususnya yang berkaitan dengan implementasi perizinan kegiatan penanaman modal. Manfaat praktis diharapkan agar penelitian ini dapat memberikan pengetahuan dan pemahaman mengenai implementasi kegiatan perizinan penanaman modal baik masyarakat umum dan para pelaku usaha.

Berdasarkan permasalahan yang diteliti oleh penulis, maka metode penelitian yang dipergunakan dalam penelitian ini adalah metode penelitian hukum normatif empiris. Penelitian hukum normatif adalah metode yang mengkaji azas-azas hukum dan peraturan perundang-undangan, buku, dokumen dan lain-lain. Sedangkan penelitian hukum empiris adalah salah satu jenis penelitian hukum yang menganalisis dan mengkaji bekerjanya hukum di dalam kehidupan masyarakat.

\section{PEMBAHASAN}

\section{Implementasi Perizinan Penanaman Modal di Kota Mataram \\ Penyelenggaraan Pelayanan Publik}

Pengertian istilah pelayanan perizinan dapat diartikan sebagai kegiatan-kegiatan dan objek tertentu yang secara khusus dimaksudkan untuk memenuhi kebutuhan masyarakat umum atau memberikan dukungan terhadap upaya meningkatkan kenikmatan dan kemudahan bagi seluruh masyarakat. Didalam hukum administrasi negara istilah pelayanan diartikan sebagai kegiatan pelayanan yang dilaksanakan oleh instansi pemerintah sebagai upaya pemenuhan kebutuhan orang, masyarakat, instansi pemerintah dan badan hukum maupun sebagai pelaksanaan ketentuan peraturan perundang-undangan.

Beberapa aturan perundang-undangan yang secara sah mengatur mengenai 
pelayanan publik:

1. Undang-Undang Nomor 25 Tahun 2009 tentang Pelayanan Publik;

2. Undang Undang Nomor 23 Tahun 2014 tentang Pemerintah Daerah;

3. Peraturan Pemerintah Nomor 96 tahun 2012 tentang Pedoman Pelaksanaan Undang-Undang Nomor 25 Tahun 2009 Tentang Pelayanan Publik;

4. Intruksi Presiden Nomor 1 Tahun 1995 tentang Perbaikan dan Peningkatan Mutu Pelayanan Aparatur Pemerintah Kepada Masyarakat;

5. Peraturan Menteri Pendayagunaan Aparatur Negara dan Reformasi Birokrasi Nomor 36 Tahun 2012 tentang Petunjuk Teknis Penyusunan Penetapan dan Penerapan Standar Pelayanan.

$\begin{array}{crr}\text { Dalam } & \text { perspektif } & \text { hukum } \\ \text { penyelenggarann } & \text { pelayanan } & \text { publik }\end{array}$ berbasis kepada negara hukum modern (negara hukum demokratis) yang merupakan perpaduan antara konsep negara hukum (rechstaat) dan konsep negara kesejahteraan (welfare staat). Negara hukum secara sederhana adalah negara yang menempatkan hukum sebagai acuan tertinggi dalam penyelenggaraan negara atau pemerintah (supremasi hukum) Konsep negara kesejahteraan adalah menempatkan peran negara tidak hanya terbatas pada sebagai penjaga ketertiban semata seperti konsep (nachtwakerstaat), tetapi dalam hal ini negara dimungkinkan untuk ikut serta dalam segala aspek kehidupan masyarakat guna mewujudkan kemakmuran masyarakat berdasarkan tujuan negara sebagaimana digariskan dalam ketentuan aturan pembukaan Undang-Undang Dasar Negara Republik Indonesia Tahun 1945.

Sebagai titik tolak beberapa sebab dalam penyelenggaraan pelayanan publik yang perlu selalu disadari adalah bahwa masalah pelayanan publik bersumber pada:

a. Adanya kewajiban pada pihak administrasi negara untuk menjalankan fungsi dan wewenangnya berdasarkan prinsipprinsip pemerintahan yang baik dan bersih.

b. Adanya pengakuan terhadap hak asasi setiap warga negara atas pemerintahan, perilaku administratif, dan kualitas hasil pelayanan yang baik

c. Adanya keanekaragaman jenis serta bidang pelayanan publik sebagai akibat dari adanya keragaman urusan dan kepentingan masyarakat yang harus dipenuhi melalui penyelenggaraan pelayanan publik.

Penyelenggaran perizinan di Dinas Penanaman Modal Pelayanan Terpadu Satu Pintu Kota Mataram dibuat dengan tujuan dalam rangka menjamin iklim investasi yang kondusif melindungi kepentingan umum dan tentunya dalam rangka sebagai fungsi pemerintah dalam kegiatan pengawasan, pengendalian, perlindungan yang berdampak pada kepentingan umum dan upaya untuk meningkatkan kualitas penyelenggaraan perizinan dengan mengedepankan kesesuaian dengan azasazas umum pemerintahan yang baik, serta untuk memberi perlindungan bagi masyarakat dari penyalahgunaan wewenang.

Berdasarkan analisa dan observasi 
penulis tentunya Dinas Penanaman Modal Pelayanan Terpadu Satu Pintu Kota Mataram pada dasarnya sudah berupaya untuk menuju ke suatu tujuan yaitu penyempurnaan penyelenggaraan pelayanan meskipun dalam kenyataanya terdapat ganjalan dan gangguan terutama terkait dengan masih adanya:

a. Diskriminasi dalam kegiatan pelayanan yaitu dalam hal ini terlihat adanya perlakuan khusus terhadap para pemangku jabatan dan rekan sejawatnya penguasa daerah jadi dalam hal ini menurut penulis mencerminkan ketidak sesuaian dengan adanya azaz non diskriminatif.

b. Masih banyaknya Calo izin yang susah ditertibkan.

c. Masih adanya pungutan liar meskipun samar dan nyaris tidak kelihatan.

d. Masih adanya promosi jabatan dan mutasi dengan memakai sistem kekerabatan dan kedekatan atau tidak sesuai keahlian.

Upaya mengimplementasikan kegiatan pelayanan publik Dinas Penanaman Modal Pelayanan Terpadu Satu Pintu Kota Mataram tentunya sudah memenuhi segala kriteria kajian di atas. Jadi dalam hal tersebut kualitas suatu pelayanan akan sangat dipengaruhi oleh transparansi dan akuntabilitas dalam penyelenggaraannya. karena keberhasilan suatu implementasi akan ditentukan bagaimana tingkat kepatuhan, lancarnya rutinitas fungsi lembaga, dan hasil kebijakan yang sesuai dengan rencana dari kebijakan. Prinsip transparansi dan akuntabilitas harus dilaksanakan dalam seluruh aspek manajemen pelayanan publik yang meliputi kebijakan perencanaan, pelaksanaan, pengawasan dan pelaporan hasil kerja

Pelayanan Perizinan Terpadu Satu Pintu adalah kegiatan penyelenggaraan pelayanan jasa perizinan yang proses pengelolaanya dimulai dari tahap permohonan sampai ke tahap penerbitan izin dokumen dilakukan secara terpadu. Pelayanan Terpadu Satu Pintu Penanaman Modal merupakan kebijakan yang diperintahkan oleh Undang-Undang Nomor 25 Tahun 2007 tentang Penananamn Modal berdasarkan aturan tersebut dimaksudkan dalam rangka untuk membantu kegiatan penanaman modal dalam memperoleh pelayanan.

Pelayanan Terpadu Satu Pintu merupakan pola pelayanan yang diselenggarakan dalam satu tempat untuk berbagai jenis pelayanan yang memiliki keterkaitan proses dilayani melalui satu pintu, dalam hal ini merupakan pelayanan izin usaha penanaman modal atau usaha.

"Menurut Utrech Izin (Verguning) merupakan suatu persetujuan dari penguasa berdasarkan ketentuan undang-undang atau peraturan pemerintah untuk dalam keadaan tertentu menyimpang dari ketentuan larangan peraturan perundangundangan dalam hal ini izin juga dapat diartikan sebagai pelepasan atau pembebasan dari suatu larangan"

"Utrecht juga mengatakan bahwa bila pembuat aturan umumnya tidak melarang suatu perbuatan, tetapi masih juga memperkenankanya asal saja diadakan secara yang ditentukan untuk masing-masing hal yang konkrit, keputusan administrasi negara yang memperkenankan perbuatan bersifat suatu izin (verguning)" 
"Menurut Adrian Sutedi Perizinan adalah salah satu bentuk pelaksanaan fungsi pengaturan dan bersifat pengendalian yang dimiliki oleh pemerintah terhadap kegiatan-kegiatan yang dilakukan oleh masyarakat. Perizinan dapat berbentuk pendaftaran, rekomendasi, sertifikasi, penentuan kuota dan izin untuk melakukan suatu usaha yang biasanya harus dimiliki atau diperoleh suatu organisasi, perusahaan, atau seseorang yang bersangkutan dapat melakukan suatu kegiatan atau tindakan"

Izin adalah perbuatan pemerintah berdasarkan ketentuan aturan perundangundangan untuk diterapkan pada peristiwa konkrit menurut prosedur dan persyaratan tertentu. Dari pengertian ada beberapa unsur dari perizinan.

a. Wewenang

Salah satu prinsip dalam negara hukum adalah wetmatigheid van bestuur (pemerintahan berdasarkan peraturan perundang-undangan) dengan kata lain setiap tindakan yang dilakukan pemerintah harus berdasarkan peraturan hukum baik dalam rangka menjalankan fungsi pengaturan maupun fungsi pelayanan.

\section{b. Izin Sebagai Bentuk Ketetapan \\ Dalam rangka melaksanakan tugas} ini kepada pemerintah diberikan wewenang dalam bidang pengaturan yang dari fungsi pengaturan tersebut yang kemudian muncul beberapa instrumen yuridis untuk menghadapi peristiwa individual yang konkrit yaitu dalam bentuk ketetapan sesuai dengan sifatnya, individual dan konkrit ketetapan ini merupakan ujung tombak dari instrumen hukum dalam penyelenggaraan pemerintah.

\section{c. Lembaga Pemerintah}

Lembaga atau kelembagaan secara teoritis adalah suatu rule of the game yang mengatur tindakan dan menentukan apakah suatu organisasi dapat berjalan dengan efektif dan efisien. Dengan demikian tata kelembagaan dapat menjadi pendorong (enabling) pencapaian keberhasilan dan sekaligus juga bila tidak dapat dalam menata penghambat (constraint) tugastugas termasuk tugas menyelenggarakan perizinan.

\section{d. Peristiwa Konkrit}

Izin merupakan instrumen yuridis yang berbentuk ketetapan yang digunakan oleh pemerintah dalam menghadapi peristiwa konkrit dan individual. Peristiwa konkrit artinya adalah peristiwa yang terjadi pada waktu tertentu, orang tertentu, tempat tertentu dan fakta hukum tertentu.

e. Proses dan Prosedur

Proses dan prosedur pelayanan perizinan dapat meliputi prosedur pelayanan perizinan, proses penyelesaian perizinan yang merupakan proses internal yang dilakukan oleh petugas, dalam setiap tahapan pekerjaan tersebut masingmasing pegawai dapat mengetahui peran masing-masing dalam proses pelayanan perizinan

f. Persyaratan Izin

Persyaratan merupakan hal yang harus dipenuhi oleh pemohon untuk memperoleh izin yang dimohonkan, 
kelengkapan persyaratan izin tersebut berupa dokumen kelengkapan atau surat-surat

\section{g. Waktu Penyelesaian Izin}

Waktu penyelesaian izin harus ditentukan oleh instansi yang bersangkutan waktu penyelesaian ditentukan sejak pengajuan permohonan di lakukan. Waktu selalu melekat pada proses perizinan karena adanya tata cara dan prosedur yang harus ditempuh seseorang dalam mengurus izin

\section{h. Biaya Perizinan}

Biaya atau tarif dalam kegiatan perizinan termasuk rinciannya yang ditetapkan dalam proses pemberian izin dengan memperhatikan hal-hal sebagai berikut:

1. Rincian biaya harus jelas untuk setiap jenis perizinan khususnya yang memerlukan tindakan penelitian, pemeriksaan, pengukuran dan pengajuan.

2. Ditetapkan dengan aturan perundang-undangan atau dan memperhatikan prosedur sesuai dengan ketentuan aturan perundang-undangan.

i. Pengawasan Penyelenggaraan Izin Kewenangan oleh aparatur pemerintahan dalam melaksanakan pemerintahan secara efisien dan adil serta memaksa para pemegang kekuasaan untuk melaksanakan pertanggungjawaban yang baik. Pengawasan internal melalui atasan langsung dan pengawasan eksternal dilakukan oleh masyarakat,
Ombudsman, KPK (untuk gratifikasi) DPRD Propinsi dan DPRD Kota.

j. Penyelesaian Pengaduan dan Sengketa.

Penyelesaian pengaduan dan sengketa oleh pemohon atau pihak yang dirugikan akibat dikeluarkanya izin maka dapat melakukan penyelesaian melalui jalur hukum yakni melalui mediasi Ombudsman atau pengadilan untuk menyelesaikan sengketa hukum perizinan tersebut.

\section{k. Sanksi}

Pelaksanaan ketentuan sanksi harus memperhatikan kriteria sebagai berikut:

1. Disebutkan secara jelas terkait dengan unsur yang dapat diberi sanksi dan sanksi apa yang harus diberikan;

2. Jangka waktu pengenaan sanksi disebutkan;

3. Mekanisme pengguguran sanksi.

1. Hak dan Kewajiban

Hak dan kewajiban pemohon dan penyelenggara harus tertuang dalam aturan perizinan diantaranya:

1. Tertulis dengan jelas;

2. Seimbang antara para pihak;

3. Wajib dipenuhi oleh para pihak

m. Tujuan Pemberian Izin

Secara umum tujuan dan fungsi dari perizinan adalah untuk pengendalian daripada aktivitas pemerintah dalam hal tertentu dimana ketentuannya berisi pedoman yang harus dilaksanakan oleh yang berkepentingan atau pejabat yang berwenang selain itu tujuan dari 
perizinan dapat dilihat dari dua sisi yaitu:

1. Dari sisi pemerintah;

2. Dari sisi masyarakat.

\section{n. Format dan Subtansi Izin}

Sesuai dengan sifatnya izin selalu dibuat dalam format tertulis sebagai ketetapan tertulis yang secara umum izin mencantumkan subtansi sebagai berikut diantaranya:

1. Kewenangan Lembaga;

2. Mencantumkan Alamat;

3. Substansi dan Diktum.

\section{o. Persyaratan}

Sebagaimana keputusan yang di dalamnya memuat ketentuan batasanbatasan diantaranya batasan mati misalnya setelah periode lima tahun maka izin tersebut mati dan tidak bisa dipakai kembali dan memuat ketentuan syarat penghapusan dan penangguhan izin tersebut:

1. Penggunaan alasan memuat tentang ketentuan-ketentuan undangundang pertimbangan hukum dan penetapan fakta;

2. Penambahan substansi lainya

Penambahan dapat berisi akibat dari pelanggaran ketentuan dalam izin seperti sanksi-sanksi yang mungkin diberikan karena ketidak patuhan.

\section{p. Fungsi Pemberian Izin}

Ketentuan tentang perizinan yaitu sebagai fungsi menciptakan ketertiban dan pengatur dimaksudkan agar izin atau izin tempat usaha baik bangunan dan bentuk kegiatan yang berlaku di masyarakat lainnya tidak bertentangan satu sama lainnya sehingga ketertiban dalam setiap segi kehidupan dapat terwujud. Sebagai fungsi mengatur dimaksudkan agar perizinan yang ada dapat dilaksanakan sesuai dengan peruntukannya.

Dinas penanaman Modal Pelayanan Terpadu Satu Pintu Kota Mataram yang merupakan Instansi pemerintah yang dalam hal ini mempunyai fungsi sebagai instansi yang mengeluarkan ketentuan izin usaha penanaman modal dalam negeri dan kegiatan penanaman modal luar negeri, tentunya penanaman modal yang mempunyai sifat langsung (direct ivestment).

Peran penting yang dimiliki Dinas Penanaman Modal Pelayanan Terpadu Satu Pintu Kota Mataram pelaksanaan terkait sebagai lembaga yang mengeluarkan ketentuan perizinan investasi tentunya merupakan implementasi dari ketentuan aturan Undang-Undang Nomor 25 Tahun 2007 tentang Penanaman Modal yang tentunya merupakan usaha dalam hal menciptakan kondisi yang menarik bagi para investor untuk melakukan kegiatan penanaman modal di daerah dan berupaya untuk mewujudkan keamanan dan iklim investasi yang kondusif, kertertiban dalam kegiatan investasi penanaman modal agar kegiatan investasi akan berjalan dengan lancar dan maksimal.

Jenis Izin di Dinas Penanaman Modal Pelayanan Terpadu Satu Pintu Kota Mataram

a. Izin Prinsip Penanaman Modal

1. Izin Prinsip Penanaman Modal Izin yang yang diberikan oleh pemerintah daerah baik tingkat 
Propinsi atau Kabupaten/Kota yang wajib dimiliki dalam setiap memulai usaha yang meliputi usaha baru atau perubahan kepemilikan dari PMDN menjadi PMA atau sebaliknya.

\section{Izin Prinsip Perubahan.}

Merupakan izin prinsip yang wajib dimiliki oleh perusahaan penanaman modal dalam rangka legalisasi perubahan rencana atau realisasi rencana yang telah ditetapkan sebelumnya.

3. Izin Prinsip Perluasan Penanaman Modal

Izin yang wajib dimiliki oleh perusahaan untuk memulai kegiatan dalam rangka perluasan usaha yamg mencakup kegiatan penambahan bidang usaha, peningkatan kapasitas produksi yang dilaksanakan baik di lokasi yang sama atau lokasi yang berbeda dengan kegiatan pelaksanaan penanaman modal sebelumnya perluasan usaha untuk penananaman modal di bidang industri adalah peningkatan kapasitas produksi untuk jenis produksi yang sama lebih besar $30 \%$ dari kapasitas produksi sebelumya yang telah diizinkan dan dilaksanakan di lokasi yang sama dengan kegiatan penanaman modal sebelumnya.

4. Izin Prinsip Penggabungan Perusahaan Penanaman Modal Izin yang wajib dimiliki oleh perusahaan yang meneruskan kegiatan usaha (surviving company) yang merupakan penggabungan dua (2) perusahaan atau lebih dalam melakukan kegiatan penanaman modal.

\section{b. Izin Usaha Penanaman Modal}

Izin yang wajib dimiliki perusahaan penanaman modal untuk melakukan dan melaksanakan kegiatan produksi/operasi komersial baik produksi barang maupun jasa sebagai pelaksanaan atas pendaftaran izin prinsip persetujuan penanaman modal kecuali ditentukan lain oleh peraturan perundang-undangan sektoral.

1. Izin Usaha Perluasan Penanaman Modal

Izin yang wajib dimiliki perusahaan penamanan modal pada saat perusahaan telah melaksanakan kegiatan produksi/operasi komersial atas penambahan kapasitas produksi yang melebihi kapasitas produksi yang telah diizinkan sebagai pelaksanaan atas pendaftaran

izin prinsip/persetujuan penanaman modal.

2. Izin Usaha Penggabungan Perusahaan Penanaman Modal

Penggabungan yang dilakukan oleh dua atau lebih perusahaan penanaman modal yang menyatakan untuk menggabungkan diri dengan perseroan lain yang telah ada dan mengakibatkan aktiva dan pasiva dari perusahaan yang menggabungkan diri tersebut beralih kepada perusahaan yang menerima penggabungan dan selanjutnya status hukum dari 
perusahaan yang menggabungkan diri tersebut berakhir karena hukum.

\section{Izin Usaha Perubahan}

Izin usaha yang wajib dimiliki oleh perusahaan pelaku kegiatan penanaman modal dalam rangka legalisasi terhadap perubahan yang mencakup perubahan bidang usaha, pimpinan perusahaan dan lokasi telah ditetapkan sebelumnya.

\section{Izin Pembukaan Kantor Cabang}

Kegiatan yang mempunyai sifat seperti laporan dan pernyataan bahwa sebuah perusahaan tersebut melakukan ekpansi usahanya ke wilayah lain dari pusat perusahaan tersebut dan melakukan kegiatan usaha yang sama dengan kegiatan yang ada pada perusahaan pusat.

\section{Izin Kantor Perwakilan Perusahaan Asing}

Adalah kantor perwakilan perusahaan asing oleh perusahaan asing atau beberapa perusahaan asing diluar wilayah Indonesia dengan maksud untuk mengurus kepentingan perusahaan atau perusahaan afiliasi di Indonesia atau negara lain untuk mempersiapkan pendirian dan pengembangan perusahaan penanaman modal asing di Indonesia.

\section{c. Izin Non Usaha}

\section{Izin Lokasi (ILOK)}

Merupakan izin yang harus dimiliki oleh perorangan atau badan usaha untuk mendapatkan tanah yang diperlukan untuk kegiatan usaha yang berlaku juga sebagai izin pemindahan hak untuk menggunakan manfaat tanah guna keperluan kegiatan investasinya terkait dengan penggunaan tanah dengan wujud tutupan permukaan bumi baik yang merupakan buatan manusia ataupun bentukan alami.

2. Izin Mendirikan Bangunan (IMB)

Izin yang diberikan oleh pemerintah daerah kepada pemilik bangunan untuk membangun baru, mengubah, memperluas, mengurangi bangunan sesuai dengan persyaratan administratif dan persyaratan teknis yang berlaku. IMB merupakan salah satu produk hukum yang mewujudkan tatanan tertentu sehingga tercipta ketertiban, keamanan, keselamatan, kenyamanan, sekaligus kepastian hukum. IMB akan melegalkan suatu bangunan yang telah ditentukan dengan adanya IMB tersebut maka kontruksi bangunan dapat dipertanggungjawabkan dengan tujuan untuk keselamatan dan kepentingan bersama.

\section{Izin Gangguan ( $\mathrm{HO}$ )}

Surat izin yang diberikan oleh pemerintah daerah dalam rangka kegiatan yang dilakukan badan usaha atau perseorangan di lokasi tertentu yang berpotensi menimbulkan bahaya, kerugian dan gangguan ketenteraman dan ketertiban umum yang dinyatakan 
dengan keterangan tidak keberatan atas lokasi usaha yang dijalankan disuatu tempat.

\section{d. Izin Usaha}

Suatu bentuk persetujuan atau pemberian izin dari pihak yang berwenang atas penyelenggaraan suatu kegiatan usaha oleh seorang pengusaha atau suatu perusahaan yang merupakan sarana dari pemerintah untuk melakukan kegiatan untuk membina, mengarahkan dan mengawasi kegiatan usaha tersebut.

1. Surat Izin Usaha Perdagangan (SIUP)

Surat izin untuk dapat melakukan usaha perdagangan yang wajib di miliki oleh badan usaha baik perorangan atau badan hukum yang melakukan kegiatan usaha perdagangan yang diterbitkan berdasarkan domisili perusahaan yang berlaku di seluruh wilayah Indonesia.

\section{Tanda Daftar Perusahaan (TDP)}

Daftar catatan resmi yang diadakan berdasarkan ketentuan undang-undang atau aturan pelaksananya dan memuat hal yang wajib didaftarkan oleh setiap perusahaan serta disahkan oleh pejabat yang berwenang.

Setiap perusahaan atau perorangan bisa mengajukan permohonan secara simultan (bersamaan) kepada pemerintah daerah setiap pemohon usaha perdagangan wajib memiliki SIUP (Surat Izin Usaha Perdagangan) dan TDP (Tanda Daftar Perusahaan) dimana SIUP dibagi menjadi 3 Golongan yaitu

a) SIUP Kecil: SIUP yang wajib dimiliki oleh perusahaan perdagangan dengan nilai kekayaan bersihnya lebih dari $50.000 .000-500.000 .000$ tidak termasuk tanah dan bangunan.

b) SIUP Menengah: SIUP Menenggah wajib dimiliki oleh perusahaan yang mempunyai kekayaan bersih lebih dari 500.000.000-10.000.000.000 tidak termasuk tanah dan bangunan.

c) SIUP Besar: SIUP yang wajib dimiliki oleh perusahaan perdagangan dengan kekayaan bersih lebih dari 10.000.000.000 tidak termasuk tanah dan bangunan.

3. Izin Usaha Industri (IUI)

Izin yang wajib dimiliki oleh perusahaan industri jenis tertentu yang dilakukan oleh badan usaha, perseorangan dan badan hukum yang mana kegiatan tersebut meliputi pengolahan dari bahan mentah, bahan baku, barang setengah jadi atau barang menjadi bernilai tinggi dalam penggunaanya termasuk rancang bangun dan rekayasa industri.

4. Tanda Daftar Industri (TDI)

Izin yang wajib dimiliki oleh perusahaan perorangan atau badan usaha yang menjalankan kegiatan industri dengan modal 5.000.000 (lima juta) sampai 200.000.000 (dua ratus juta). 


\section{Tanda Daftar Gudang (TDG) \\ Merupakan Izin yang digunakan oleh pemerintah dalam kegiatan pengawasan dan pengendalian atas penyelenggaraan pergudangan yang berkaitan dengan kegiatan usaha berupa penyimpanan barang di dalam ruang yang tertutup.}

\section{Surat Izin Usaha Minuman Beralkohol (SIUP MB) \\ Surat Izin yang dikeluarkan kepala daerah yang berkenaan kegiatan usaha perdagangan khusus minuman beralkohol golongan $\mathrm{B}$ dan $\mathrm{C}$. Minuman beralkohol berdasarkan kandunganya dibedakan menjadi 3 (tiga) diantaranya yaitu}

a) Minuman berakohol golongan A dengan kadar etil alkohol atau etanol (C2H5OH) sampai 5\%.

b) Minuman beralkohol golongan $B$ dengan kadar etil alkohol atau etanol $(\mathrm{C} 2 \mathrm{H} 5 \mathrm{OH})$ lebih dari $5 \%$ sampai dengan $20 \%$.

c) Minuman beralkohol golongan $\mathrm{C}$ dengan kadar etil alkohol atau etanol $(\mathrm{C} 2 \mathrm{H} 5 \mathrm{OH})$ lebih dari $20 \%$ sampai dengan $55 \%$.

\section{Izin Usaha Jasa Konstruksi (IUJK)}

Izin untuk melakukan kegiatan usaha dibidang kontruksi baik sebagai kontraktor atau konsultan yang meliputi bidang usaha pelaksanaan kontruksi, perencana kontruksi dan pengawas kontruksi atau jasa kontruksi terintegrasi.
8. Tanda Daftar Usaha Pariwisata (TDUP)

Dokumen resmi yang diterbitkan oleh Dinas, Suku Dinas yang berisi data dan informasi mengenai rencana mendirikan usaha pariwisata dan atau penyelenggaraan usaha pariwisata.

\section{Izin Reklame}

Izin yang diberikan kepada Badan usaha atau orang / perorangan untuk menyelenggarakan/memasang reklame dalam jangka waktu tertentu.

\section{Izin Trayek}

Pemberian izin trayek kepada orang atau pribadi atau badan yang menyediakan pelayanan angkutan penumpang umum pada satu atau beberapa trayek tertentu dalam Wilayah Daerah.

\section{Izin Usaha Angkutan}

Izin tertulis yang dikeluarkan Pemerintah terhadap orang/badan untuk melakukan usaha atau kegiatan pemindahan orang dan atau barang dari satu tempat ketempat lain dengan menggunakan kendaraan darat.

Implementasi aturan hukum dalam hal ini adalah Peraturan Daerah Kota Mataram Nomor 1 Tahun 2016 tentang Penyelenggaraan Perizinan di Kota Mataram yang juga mengatur klasifikasi dan penggolongan jenis-jenis izin yang ada di Kota Mataram beserta persyaratan yang digunakan untuk mendapatkan izin dan dasar hukum izin tersebut.

Peraturan Daerah No 1 tahun 2016 tentang Penyelenggaran Perizinan di Kota Mataram dibuat dalam rangka guna 
menjamin dalam upaya untuk menarik minat investor menanamkan modalnya di Kota Mataram, iklim investasi yang kondusif di Daerah Kota Mataram, memberikan kepastian hukum, melindungi kepentingan umum dan memelihara lingkungan.

Peraturan ini dibuat tentunya dalam rangka sebagai fungsi pemerintah dalam kegiatan pengawasan, pengendalian, perlindungan dalam kegiatan kemasyarakatan yang berdampak pada kepentingan umum dan upaya untuk meningkatkan kualitas penyelenggaraan perizinan yang tentunya dengan mengedepankan kesesuaian dengan azasazas umum pemerintahan yang baik serta untuk memberi perlindungan bagi masyarakat dari penyalahgunaan wewenang di dalam penyelenggaraan proses perizinan yang tentunya berdasarkan pada azas tentang pelayanan publik.

Dalam hal kegiatan pelayanan perizinan tentunya harus mempunyai dan memuat sasaran yang harus dapat terealisasi agar terwujudnya keberhasilan dalam kegiatan pelayanan publik, yang mana sasaran tersebut terdiri dari:

1. Tercapainya tingkat kepuasan masyarakat terhadap pelayanan perizinan;

2. Berkurangnya konflik dan sengketa hukum;

3. Tercapainya kemudahan akses pelayanan perizinan;

4. Tercapainya koordinasi dan keterpaduan antara satuan kerja perangkat daerah dalam penyelenggaraan perizinan.
KENDALA - KENDALA PERIZINAN PENANAMAN MODAL DI KOTA MATARAM

Adanya Rapat Tim Koordinasi Teknis Yang Membuat Birokrasi Dianggap Lama Oleh Pelaku Usaha Penanaman Modal di Kota Mataram

Birokrasi yang tidak efisien yang tentunya ditandai dengan panjangnya rantai birokrasi proses perizinan hal ini akan mengakibatkan terjadinya biaya yang tinggi yang pada akhirnya dapat menghambat laju investasi. Kendala kordinasi tentunya merupakan suatu kendala yang sangat serius apalagi setelah pelaksanaan otonomi daerah. Banyak peraturan pemerintah yang tidak bisa berjalan secara efektif karena adanya tarik menarik suatu kepentingan antara pemerintah pusat dan pemerintah daerah baik pemerintah kota/kabupaten ataupun pemerintah propinsi karena semuanya merasa paling mempunyai kepentingan atas kegiatan penanaman modal di daerah. Kebijakan otonomi daerah membuat para investor dibebani dengan lamanya proses perizinan dan terkesan berbelit-belit sehingga membutuhkan rentang waktu yang lama dan disertai dengan adanya biaya yang besar.

Permasalahan birokrasi tentunya sudah menjadi permasalahan utama karena jalur birokrasi yang dinilai terlalu panjang yang dirasakan oleh para pelaku penananaman modal sehingga memunculkan atau terciptanya situasi yang kurang kondusif untuk iklim penanaman modal di daerah. Kegiatan perizinan di daerah belum secara signifikan mampu memperbaiki kualitas pelayanan dalam hal perizinan, bahkan ada kecenderungan otonomi daerah malah menjadikan jumlah biaya menjadi 
meningkat dan birokrasi perizinan semakin panjang. Jadi hal ini menandakan bahwa masih belum bisa tercapainya maksud dan tujuan dari UU No. 25 Tahun 2009 tentang Pelayanan Publik yaitu pasal 2 (dua).

Dinas Penanaman Modal Pelayanan Terpadu Satu Pintu Kota Mataram yang selanjutnya disebut DPMPTSP terkait lambatnya birokrasi dan prosedur perizinan hal ini bukan tanpa alasan ada beberapa hal yang membuat proses perizinan ini lambat diantaranya dengan adanya tim teknis yang dilibatkan di dalam proses perizinan di Dinas Penanaman Modal Pelayanan Terpadu Satu Pintu Kota Mataram tentunya keberadaanya mempunyai fungsi salah satunya untuk mengurangi resiko mengingat tidak adanya imunitas yang diberikan oleh negara kepada karyawan Dinas Penanaman Modal Pelayanan Terpadu Satu Pintu Kota Mataram akibat dari kesalahan termasuk kesalahan administratif perizinan tersebut.

Dalam kegiatan koordinasi rapat yang dilakukan oleh tim yang sudah tergabung sebagai tim teknis perizinan di Dinas Penanaman Modal Pelayanan Terpadu Satu Pintu Kota Mataram dalam kaitanya dengan hal ini terbentur dengan anggaran tim rapat yang telah diajukan di Dinas Penanaman Modal Pelayanan Terpadu Satu Pintu Kota Mataram, jadi terkait anggaran tersebut Dinas Penanaman Modal Pelayanan Terpadu Satu Pintu Kota Mataram dalam hal ini harus menunggu dahulu berapa jumlah berkas izin yang masuk kemudian setelah berkas terkumpul maka akan dibuatkan undangan rapat kapan rapat tim itu dilaksanakan.

Tim koordinasi yang dilaksanakan oleh DPMPTSP Kota Mataram merupakan implementasi dari ketentuan aturan
Peraturan Menteri Dalam Negeri Nomor 24 tahun 2006 tentang Pedoman Penyelenggaraan Pelayanan Terpadu Satu Pintu. Adanya tim koordinasi tersebut hal ini berkaitan dengan resiko keputusan yang di ambil mempunyai konsekwensi berat mengingat hal tersebut erat berkaitan dengan masalah gangguan lingkungan, keamanan dan kenyamanan masyarakat dan tata ruang daerah tentunya adanya tim koordinasi menurut penulis merupakan tindakan yang tepat.

Permasalahan dalam masalah ini muncul dikarenakan adanya jadwal rapat tim koordinasi akibat ketentuan rapat tersebut mengakibatkan terhambatnya pelayanan perizinan karena harus menentukan jadwal rapat mengantarkan surat undangan rapat yang tentunya semua kegiatan tersebut memakan waktu dan proses, terkait dengan adanya kendala anggaran rapat karena dalam kegiatan rapat tersebut dianggarkan sebulan 4 kali rapat atau setahun sebanyak 48 kali rapat dimana pengaturanya dalam sebulan 2 kali rapat izin gangguan dan 2 kali rapat izin reklame dan izin lokasi.

Menurut penulis dalam hal ini mengingat pentingnya fungsi dari tim koordinasi terhadap penyelenggaraan kegiatan pelayanan perizinan menyiratkan bahwa kurangnya sosialisasi yang dilakukan oleh Dinas Penanaman Modal Pelayanan Terpadu Satu Pintu Kota Mataram tentunya hal ini dapat penulis ketahui dari para pelaku usaha yang banyak mengeluhkan keberadaan tim koordinasi teknis tersebut. Lancarnya pelaksanaan rutinitas fungsi bahwa keberhasilan implementasi ditandai dengan lancarnya rutinitas fungsi dan tidak adanya masalahmasalah yang dihadapi, terwujudnya 
kinerja dan dampak yang dikehendaki.

\section{Munculnya Calo Izin dan Pungutan Liar Yang Menghambat Kegiatan Perizinan}

Calo adalah orang yang menjadi perantara dan memberikan jasanya untuk menguruskan sesuatu berdasarkan upah. Calo bekerja sebagai pemberi jasa alternatif atau jalan pintas bagi seseorang secara tidak resmi. Seorang calo akan berusaha mencari keuntungan dengan menggandakan biaya asli suatu produk atau jasa, memberikan penawaran dengan biaya yang besar dan tentunya berbeda dari biaya sebenarnya.

Pungutan liar yang selanjutnya disebut pungli merupakan perbuatan yang dilakukan oleh seseorang atau Pegawai Negeri atau Pejabat Negara dengan cara meminta pembayaran sejumlah uang yang tidak sesuai atau tidak berdasarkan peraturan yang berkaitan dengan pembayaran tersebut. Hal ini sering disamakan dengan perbuatan pemerasan.

Kegiatan untuk memberantas keberadaan calo dan pungutan liar Pemerintah Kota Mataram dan Ombusdman yang mempunyai tugas diantaranya yaitu melakukan langkahlangkah untuk menindaklanjuti laporan atau informasi mengenai terjadinya penyimpangan oleh penyelenggara negara dalam melaksanakan tugas dan fungsi dalam memberikan pelayanan umum.

Begitu seriusnya pemerintah Kota Mataram dalam kegiatan pemberantasan pungli dan percaloan termasuk di dinas Penanaman Modal Pelayanan Terpadu Satu Pintu Kota Mataram hal ini terlihat dari telah dikukuhkanya tim Saber Pungli oleh Walikota pada 14 desember 2016. Pengukuhan tim saber pungli merupakan agenda penting di Kota Mataram selain sebagai bentuk pelaksanaan Peraturan Presiden Nomor 87 Tahun 2016 tentang Satgas Saber Pungli yang kemudian ditindak lanjuti dengan Intruksi Menteri Dalam Negeri tentang Pengawasan Pungli dan Penyelenggaraan Pemerintah Daerah, tindakan-tindakan pungli dan percaloan dalam penyelenggaraan kegiatan yang berkaitan dengan pelayanan publik akan menyebabkan lambatnya proses perizinan dalam kegiatan pelayanan publik dan kegiatan usaha penanaman modal di Kota Mataram.

Kegiatan pemberantasan budaya pungli dan pengawasan pelayanan publik tersebut juga dibantu oleh Dewan Perwakilan Rakyat Komisi II Bidang Ekonomi dalam rangka pengawasan implementasi Peraturan Daerah terkait pengawasan keuangan daerah, perpajakan, retribusi daerah, perbankan dan perusahaan daerah. Penulis beranggapan bahwa dalam kegiatan percaloan dan pungutan liar tersebut merupakan tindakan melanggar hukum jadi dengan adanya calo dalam perizinan menurut penulis hal ini mencerminkan dan menggambarkan tidak efektifnya pesan dari ketentuan UU No. 25 tahun 2007 tentang Penanaman Modal.

\section{Keterbatasan Fasilitas Kerja}

Fasilitas adalah sarana untuk melancarkan dan memudahkan pelaksanaan fungsi. Fasilitas merupakan komponen individual dari penawaran yang mudah ditumbuhkan atau dikurangi tanpa mengubah kualitas dan model jasa. secara sederhana yang dimaksud dengan fasilitas adalah suatu sarana fisik yang dapat memproses suatu masukan (input) menuju keluaran (output) yang diinginkan. 
Suatu pencapaian tujuan instansi, diperlukan alat atau sarana pendukung yang digunakan dalam aktivitas sehari-hari di instansi tersebut, fasilitas yang digunakan bermacam-macam bentuk jenisnya maupun manfaatnya yang disesuaikan dengan kebutuhan dan kemampuan kantor.

Untuk mencapai tujuan instansi faktor yang mendukung, salah satu diantaranya adalah fasilitas kerja karyawan yang merupakan pendukung bagi kelancaran tugas yang mereka kerjakan. Fasilitas kerja adalah sarana pendukung dalam aktivitas intansi berbentuk fisik, dan digunakan dalam kegiatan normal instansi, memiliki jangka waktu kegunaan yang relatif permanen dan memberikan manfaat untuk masa yang akan datang.

Fasilitas kerja sangatlah penting bagi instansi atau kantor karena dapat menunjang kinerja karyawan, seperti dalam penyelesaian pekerjaan. Pada suatu instansi untuk mencapai suatu tujuan diperlukan alat pendukung yang digunakan dalam proses atau aktifitas di instansi tersebut. Fasilitas yang digunkan oleh setiap instansi bermacam-macam bentuk, jenis dan manfaatnya. Semakin besar aktifitas suatu instansi atau kantor tentunya maka harus semakin lengkap pula fasilitas dan sarana pendukung dalam proses kegiatan pekerjaan dapat dikerjakan sesuai dengan yang diharapkan.

Hal keterbatasan fasilitas, bekerja tidak akan optimal jika tidak didukung oleh fasilitas kerja yang memadai hal ini terjadi dalam kegiatan dan aktifitas apapun dan dimanapun termasuk di Dinas Penanaman Modal Pelayanan Terpadu Satu Pintu Kota Mataram walaupun dikategorikan mempunyai sumber daya manusia yang bagus tanpa didukung oleh sarana dan prasarana kerja tentunya maka hasilnya tidak akan menjadi bagus dan tidak kelihatan profesional.

Tanpa bantuan fasilitas kerja dari kantor yang memadai para karyawan akan lebih sulit untuk menyelesaikan pekerjaan mereka, dan juga tidak hanya masalah kualitas hasil kerja mereka saja yang menjadi dampaknya tentunya juga akan mengakibatkan panjangnya proses dan waktu pekerjaan karena terbentur dengan ketersediaanya fasilitas penunjang kerja tersebut. Akan sangat wajar jika pekerjaan akan menjadi lama jika tidak ditunjang dengan fasilitas kerja yang kurang memadai.

Apabila ada kekurangan fasilitas yang mendukung kegiatan dalam pelaksanaan pelayanan publik menurut penulis ada hal yang sifatnya wajib untuk dipenuhinya segala sesuatu yang dibutuhkan dalam menunjang kegiatan pelayanan perizinan termasuk fasilitas kerja petugas. Berdasarkan ketentuan diatas fasilitas kerja yang kurang memadai tentunya juga akan mempengaruhi kualitas kinerja seorang karyawan.

Jika dalam sebuah sub bidang usaha mempunyai satu komputer dan satu printer misalnya dengan tingkat intensitas pekerjaan yang tinggi dan tidak mengerjakan satu izin saja tapi mencetak tujuh izin yaitu diantaranya:

1. Surat Izin Usaha Perdagangan (SIUP);

2. Tanda daftar Perusahaan (TDP);

3. Tanda Daftar Gudang (TDG);

4. Tanda Daftar Industri (TDI);

5. Izin Usaha Industri (IUI);

6. Penutupan Kantor;

7. Pembukaan Kantor Cabang. 
Maka hal ini tentunya sungguh tidak efektif dan tidak efisien, Dengan melihat dampak negatif akibat kurangnya fasilitas penunjang dalam kegiatan bekerja tentunya Dinas Penanaman Modal Pelayanan Terpadu Satu Pintu Kota Mataram agar segera menambah fasilitas yaitu komputer dan printer demi kelancaran dan efisienya waktu dalam pengurusan izin sehingga setidaknya dapat meminimalisir panjangnya prosedur dalam pengurusan izin tersebut, Tentunya jika fasilitas tersebut dapat direalisasikan maka hasil kerja yang diciptakan juga akan menjadi maksimal dan tepat waktu

Penulis melihat adanya kesenjangan antara Das Sollen (kaedah hukum yang berisi kenyataan normatif berdasarkan apa yang seharusnya dilakukan) dengan Das Sein (kenyataan alamiah atau peristiwa konkrit) dimana pada kenyataan penyelenggara kegiatan perizinan pelayanan publik tidak mendapatkan fasilitas apa yang seharusnya di dapatkan guna menciptakan pelayanan publik yang tepat waktu dan profesional.

Berdasarkan uraian tersebut penulis beranggapan bahwa untuk mengadakan pelayanan publik dalam hal ini terkait dengan perizinan dalam rangka menciptakan pelayanan yang maksimal segala sesuatu yang terkait dengan fasilitas kerja yang dibutuhkan oleh pegawai harus dipenuhi oleh penyelengara pelayanan publik (pemerintah) guna menciptakan pelayanan yang maksimal tanpa adanya kesan memaksakan.

\section{Promosi dan Mutasi Memunculkan Hambatan Dalam Pelayanan.}

Untuk mencapai tujuan organisasi pemerintahan diperlukan pegawai yang mempunyai rasa tanggung jawab, keterampilan dan kemampuan untuk melaksanakan kewajiban serta pekerjaannya dengan baik dan efisien, untuk memperoleh pegawai demikian diperlukan adanya suatu ketentuan yang mengatur kedudukan, kewajiban, hak dan pembinaan pegawai yang dilaksanakan berdasarkan suatu sistem kepegawaian obyektif, yaitu sistem karier dan sistem prestasi kerja.

Kedudukan seorang pegawai pada umumnya ditentukan dalam surat keputusan pimpinan organisasi atau instansi tentang pengangkatannya, baik yang menyangkut tingkat jabatan atau kedudukan, maupun tingkat sistem upah yang berlaku baginya. Sedangkan kewajiban dan hak pegawai merupakan dua hal yang timbul karena jabatan itu dan keduanya harus seimbang, yang satu tidak boleh diutamakan dari yang lainnya. Promosi Jabatan merupakan perpindahan yang memperbesar authority dan responsibility pegawai ke jabatan yang lebih tinggi di dalam suatu organisasi sehingga kewajiban hak, status dan penghasilanya semakin besar.

Mutasi PNS merupakan bagian dari pembinaan guna memberikan pengalaman kerja, meningkatkan kinerja dan tanggung jawab PNS. Pelaksanaan desentralisasi sering digambarkan dengan meningkatnya kewenangan kepala daerah termasuk di bidang manajemen kepegawaian sebagaimana yang dimaksud pada Pasal 55 Undang-Undang Aparatur Sipil Negara salah satunya mutasi. Mutasi merupakan perpindahan pekerjaan seseorang dalam suatu SKPD yang memiliki tingkatan yang sama dari posisi pekerjaan sebelumnya. Undang-undang Nomor 5 Tahun 2014 
tentang Aparatur Sipil Negara merupakan sebuah sumber hukum (basic legal) untuk pemerintah pusat maupun pemerintah daerah dalam menerapkan kebijakan manajemen pegawai terutama pada proses mutasi pegawai ASN. Implikasi dan makna yang terkandung dalam ketentuan aturan ini adalah pegawai akan di pacu untuk bekerja secara optimal dan maksimal dalam melaksanakan tugas sebagai Aparatur Sipil Negara.

Promosi juga merupakan sarana yang dapat mendorong pegawai untuk lebih baik atau lebih bersemangat dalam melakukan suatu pekerjaan, dengan melihat fakta tersebut maka penilaian kerja yang mengarah pada promosi jabatan harus dilakukan dengan efektif agar dapat diterima semua pihak tanpa ada yang merasa dirugikan. Promosi mempunyai arti penting bagi sebuah instansi karena dengan adanya promosi akan dapat meningkatkan semangat kerja pegawai. Jika promosi direalisasikan kepada pegawai yang berprestasi tinggi maka akan menimbulkan rangsangan bagi para pegawai untuk meningkatkan semangat kerja. Promosi pada dasarnya mempunyai nilai karena dengan promosi berarti ada kesempatan bagi pegawai untuk maju disamping itu promosi merupakan bukti pengakuan antara lain terhadap prestasi kerja yang dicapai pegawai.

Kedua hal ini merupakan harapan yang harus dapat ditimbulkan, bilamana suatu instansi melaksanakan promosi. Sudah tentu dengan promosi tidak hanya diharapkan pada kedua hal tersebut, tetapi jauh lebih luas daripada itu. Suatu jabatan pada suatu saat akan ditinggalkan. Hal ini disebabkan oleh beberapa hal, misalnya karena pensiun, keluar, sakit, meninggal dunia, kerjanya menurun dan sebagainya. Dalam hal ini jabatan yang kosong harus diisi, dimana salah satu cara mengisi kekosongan tersebut adalah dengan jalan promosi.

Terhadap pengangkatan dalam jabatan fungsional adalah berdasarkan pada keahlian apa yang dibutuhkan untuk jabatan itu dan syarat-syarat obyektif lainnya. Sedangkan dalam hal pengangkatan struktural adalah sangat erat dengan jenjang kepangkatan yang ditetapkan untuk jabatan itu

Penerapan kebijakan promosi dan mutasi pegawai negeri sampai pada saat ini masih seringkali kita jumpai masih menggunakan sistem yaitu pengangkatan dan penempatan seorang pegawai masih berdasarkan dari latar belakang hubungan pribadi antara pihak yang satu atau pihak yang mengangkat dan pihak yang diangkat (Patronage System).

Tentunya pemerintah Kota Mataram dalam melaksanakan kebijakan yang menyangkut dengan mutasi menyadari dan selalu berusaha untuk lebih tanggap dengan berbagai tantangan reformasi birokrasi terutama dalam menciptakan kondisi dan iklim pelayanan yang kondusif dalam kegiatan pelayanan publik di Kota Mataram dan mampu menciptakan kualitas dan kapabilitas pagawai dan bukan menciptakan sebuah kemunduran dalam menerapkan kebijakan pegawai.

Pada kenyataanya adanya agenda promosi dan mutasi di Lingkungan Pejabat Pemerintah Kota pegawai Mataram sangat berdampak bagi kinerja karyawan terutama karyawan di instansi pelayanan masyarakat karena menyebabkan kurang maksimalnya kinerja dari karyawan tersebut. Adanya agenda promosi pejabat akan membuat 
program dan kebijakan yang telah ada menjadi berubah-ubah dan hal ini sering mengakibatkan kebingungan karyawan di Dinas Penanaman Modal Pelayanan Terpadu satu Pintu Kota Mataram.

Seharusnya kebijakan promosi dan mutasi pegawai ASN dapat menciptakan suatu netralitas yang tinggi dan berlandaskan pada merit system (pengangkatan pegawai berdasarkan pada kecakapan yang dimiliki) Dalam konsep ini mutasi dan promosi pegawai diharapkan mampu mendorong dan menciptakan penerapan reformasi birokrasi dan reformasi tata kelola pemerintahan daerah. Sebab reformasi birokrasi sendiri bertujuan untuk mengubah struktur, tingkah laku dan keberadaan telah lama agar menjadi sesuatu yang baru dan menjadi lebih baik baik dari sebelumnya adanya peningkatan dan progres yang signifikan dalam artian positif bukan malah sebaliknya.

UPAYA DINAS PENANAMAN MODAL PELAYANAN TERPADU SATU PINTU KOTA MATARAM MEMPERCEPAT PROSES PERIZINAN

\section{Program Sehati (Sehari Pasti Jadi)}

Berdasarkan ketentuan Peraturan Pemerintah Nomor 38 Tahun 2007 tentang Pembagian Urusan Pemerintahan Pusat, Pemerintah Daerah Propinsi, Pemerintah Daerah Kota dan dalam mengimplementasikan ketentuan aturan Undang-Undang Nomor 25 Tahun 2009 tentang Pelayanan Publik khususnya yang berkaitan dengan azas pelayanan publik sendiri yaitu azas kepentingan umum, azas kecepatan, kemudahan, dan keterjangkauan program SEHATI dilakukan oleh Dinas Penanaman Modal Pelayanan Terpadu Satu
Pintu Kota Mataram yang diluncurkan pada tanggal 2 Mei 2016.

Program sehati merupakan terobosan dan inovasi baru pemerintah Kota Mataram melalui Dinas Penanaman Modal pelayanan Terpadu Satu Pintu Kota Mataram dalam peningkatan pelayanan publik terutama di bidang perizinan sektor mikro. Sebagaimana kita ketahui bahwa permasalahan bagi usaha kecil adalah terbatasnya modal usaha. Salah satu cara memenuhi modal usaha tersebut adalah melalui pemenuhan pinjaman yang terutama kepada lembaga keuangan formal. Tentunya program izin SEHATI lahir dalam rangka mengimplementasikan ketentuan Undang-Undang Nomor 25 Tahun 2007 tentang Penanaman Modal dan juga dalam rangka menciptakan iklim investasi yang kondusif yang mana pada ketentuan aturan Undang-Undang Nomor 25 Tahun 2007 tentang Penanaman. SEHATI juga merupakan implementasi dari ketentuan aturan UU No. 20 Tahun 2008 tentang Usaha Mikro Kecil dan Menengah hal ini tertuang dalam pasal 7 sampai pasal 12 .

Melalui program SEHATI tersebut bertujuan agar sekiranya Dinas Penanaman Modal pelayan Terpadu satu pintu Kota Mataram dapat memberikan pelayanan yang prima kepada masyarakat Kota Mataram tentunya hal ini harus juga ikut campurnya Camat dan Lurah membantu dalam kegiatan mensosialisasikan program tersebut agar sekiranya program SEHATI tersebut dapat diketahui dan dapat dimanfaatkan oleh seluruh masyarakat.

Sayangnya Izin SEHATI tidak bisa dilaksanakan pada jenis permohonan izin usaha khusus, yang memerlukan kajian tim teknis dan evaluasi tim terpadu seperti izin 
IMB dan sejenisnya karena sebelum izin tersebut keluar diperlukan adanya kajian tim teknis. Tentunya izin yang termasuk dalam kategori SEHATI tersebut dapat diproses apabila persyaratan administrasi telah lengkap dan tidak ada kekurangan satu apapun maka hal ini dapat dijamin kalau izin tersebut akan dapat segera diterbitkan dalam sehari apabila pagi di masukan berkas permohonanya maka sore akan bisa diambil oleh pemohon dan biasanya izin tersebut apabila reguler dapat diselesaikan dengan rentang waktu tiga hari. Tentunya izin yang termasuk dalam kategori SEHATI tersebut dapat diproses apabila persyaratan administrasi telah lengkap dan tidak ada kekurangan satu apapun maka hal ini dapat dijamin kalau izin tersebut akan dapat segera diterbitkan dalam sehari apabila pagi di masukan berkas permohonanya maka sore akan bisa diambil oleh pemohon dan biasanya izin tersebut apabila reguler dapat diselesaikan dengan rentang waktu tiga hari.

Kecuali izin reklame dari delapan izin tersebut jenis dari izin SEHATI akan dilayani secara gratis oleh pemerintah dengan harapan hal ini akan meningkatkan kesadaran masyarakat untuk mengurus izin baik izin usaha ataupun izin non usaha sehingga dapat berpengaruh positif terhadap perekonomian masyarakat Kota Mataram untuk bertambah baik dan investasi bisa berkembang meningkat pesat.

Kegiatan implementasi aturan hukum ketentuan aturan UU No 25 tahun 2009 tentang Pelayanan Publik dalam rangka memberikan pelayanan yang prima kepada masyarakat, penciptakan iklim investasi yang kondusif yang mana pada ketentuan aturan UU No 25 Tahun 2007 tentang penanaman modal sesuai dengan azas dari pelayanan publik yaitu:

1. Azas kecepatan;

2. Azas kemudahan.

Pada dasarnya program SEHATI (sehari pasti jadi) merupakan implementasi ketentuan program dalam rangka menarik dan menumbuhkan kesadaran masyarakat akan pentingnya izin usaha yang dapat dijadikan jaminan dan legalitas usaha khususnya mendorong sektor usaha mikro. Izin SEHATI merupakan salah satu cara dari Pemerintah Kota Mataram dalam usaha menghilangkan kesan terutama pada pengusaha mikro bahwa prosedur perizinan sulit ditembus dan mahal.

\section{Izin Paket}

Pelaksanaan ketentuan azas dari Undang-Undang No. 25 Tahun 2009 tentang Pelayanan Publik yaitu azaz kecepatan, kemudahan dan keterjangkauan hal ini di tanggapi oleh Pemerintah Kota Mataram dan juga karena banyaknya tuntutan dari masyarakat Kota Mataram bahwa pelayanan perizinan harus mengedepankan adanya efisiensi dalam hal pelayanan baik sisi waktu dan juga dari sisi biaya, Masyarakat pelaku usaha di Kota Mataram tentunya sangat membutuhkan proses perizinan yang cepat dan sederhana hal ini tentunya menjadi sebuah agenda kerja Dinas penanaman modal Pelayanan Terpadu Satu Pintu Kota Mataram dalam menyikapi permasalahan perizinan tersebut karena dalam hal pengajuan perizinan harus satu persatu sesuai dengan pembagian izin tersebut

Melihat perkembangan dunia usaha tersebut tentunya pemerintah harus bisa menyediakan pilihan terhadap masyarakat 
dalam melaksanakan pendaftaran izin tersebut bisa dilaksanakan secara sendirisendiri perjenis izin dan dapat secara paralel atau paket yang terdiri dari berbagai izin penyederhanaan proses pelayanan publik dengan mendasarkan regulasi yang ada dan sumber daya manusia serta sarana yang tersedia di Dinas Penanaman Modal Pelayanan Terpadu Satu Pintu Kota Mataram.

Berdasarkan latar belakang tersebut dicetuskanya sebuah inovasi di Dinas Penanaman Modal Pelayanan Terpadu Satu Pintu Kota Mataram yaitu Pelayanan Perizinan Paralel (paket) adalah pelayanan perizinan dengan sistem paralel dengan sistem paralel tersebut membuat waktu dan proses perizinan menjadi lebih singkat. Karena dengan penggabungan ini pemohon dapat menggabungkan beberapa izin dan dapat didaftarkan dalam satu kali saja dan diproses secara terpadu dan bersamaan serta pengurusan administrasi berbasis teknologi aplikasi, input data cukup dilakukan sekali dan administrasi dapat dilakukan secara simultan atau secara bersamaan.

Tujuan inovasi ini secara umum adalah untuk melaksanakan reformasi birokrasi di bidang pelayanan publik dengan tujuan untuk meningkatkan kualitas pelayanan publik di Kota Mataram dengan harapan dapat meningkatkan kesadaran masyarakat untuk mengurus izin dan menciptakan iklim investasi yang baik di Kota Mataram. Adapun tujuan khususnya dalam inovasi penerapan izin paralel (paket) ini adalah:

1. Terwujudnya penyederhanaan persyaratan dan proses perizinan usaha serta memangkas dan menyederhanakan waktu kunjungan masyarakat ke Dinas penanaman Modal pelayanan Terpadu satu Pintu Kota Mataram;

2. Terwujudnya pelayanan publik yang menerapkan standar pelayanan publik;

3. Terwujudnya pelayanan yang pasti dalam, waktu, biaya dan persyaratan;

4. Terwujudnya kepastian hukum dan transparansi bagi masyarakat dan aparatur dalam pelayanan publik.

Izin paket merupakan kebijakan dalam rangka penyederhanaan proses perizinan yaitu proses pelayanan izin secara paralel agar proses kegiatan pelayanan perizinan dapat selesai dengan singkat dimana berkas dari kepengurusan izin bisa terdiri dari lebih dari satu jenis izin saja dan dapat dimasukan secara bersamaan.

Izin paket merupakan cara dan strategi dari Dinas Penanamaan Modal Pelayanan Terpadu Satu Pintu Kota Mataram dalam kegiatan usahanya membuat iklim yang kondusif dalam kegiatan investasi karena hal ini akan menimbulkan hubungan timbal balik saling menguntungkan jika investasi berkembang maka ekonomi daerah akan dapat tumbuh dengan pesat dalam melaksanakan kegiatan pelayanan publik tentunya setiap daerah harus mampu memberikan kemudahan-kemudahan sebagai sarana dan fasilitas dalam rangka menarik pelaku investasi

Kemudahan itu tentunya meliputi aspek kemudahan salah satunya di sektor birokrasi, daerah yang mempunyai banyak keunggulan dan banyak menawarkan program yaitu dalam hal kemudahan dan sistem penunjang investasi, maka daerah tersebut akan mendatangkan banyak investor. Dinas Penanaman Modal 
Pelayanan Terpadu Satu Pintu Kota Mataram tahu betul bahwa pelayanan publik merupakan salah satu unsur yang sangat penting dalam menunjang kegiatan penanaman modal di Kota Mataram.

Tentunya dalam hal ini izin paket di Dinas Penanaman Modal Pelayanan Terpadu satu Pintu Kota Mataram merupakan implementasi dari ketentuan UU No 25 tahun 2007 tentang penanaman modal tentang kemudahan dan kesederhanaan proses perizinan yang bertujuan dalam rangka menarik investasi dalam rangka memenuhi sumber-sumber pembiayaan pembangunan.

\section{Menciptakan Standar Operasional Pelayanan}

Standar Operasional Prosedur selanjutnya disingkat (SOP) adalah dokumen yang berkaitan dengan prosedur yang dilakukan secara kronologis untuk menyelesaikan suatu pekerjaan yang bertujuan untuk memperoleh hasil kerja yang paling efektif dari para pekerja dengan biaya serendahrendahnya dan waktu yang sesingkatsingkatnya.

Oleh karenanya secara otomatis berbagai fasilitas pelayanan public harus lebih didekatkan pada masyarakat, sehingga mudah dijangkau oleh masyarakat. Pemerintah Pusat mengeluarkan sejumlah kebijakan untuk meningkatkan kinerja instansi pemerintah dan kualitas pelayanan publik, antara lain kebijakan tentang Penyusunan Sistem dan Prosedur Kegiatan, Penyusunan Akuntabilitas Kinerja Instansi Pemerintah (Inpres No. 7 Tahun 1999), dan Pedoman Umum Penyusunan Indeks Kepuasan Masyarakat Unit Pelayanan Instansi Pemerintah (SK Menpan

\section{No.KEP/25/M.PAN/2/2004).}

Langkah ini sebenarnya bukanlah hal baru, karena sebelumnya kebijakan serupa telah dikeluarkan pemerintah dalam bentuk Keputusan Menpan maupun Instruksi Presiden (Inpres). Kebijakan itu ternyata tidak secara otomatis menyelesaikan permasalahan pelayanan publik oleh instansi pemerintah yang selama ini bercitra buruk, berbelit-belit, lamban, dan berbiaya mahal.

Hal tersebut berkaitan dengan persoalan seberapa jauh berbagai peraturan pemerintah tersebut disosialisasikan di kalangan aparatur pemerintah dan masyarakat, serta bagaimana infrastruktur pemerintahan, dana, sarana, teknologi, kompetensi sumberdaya manusia (SDM), budaya kerja organisasi disiapkan untuk menopang pelaksanaan berbagai peraturan tersebut, sehingga kinerja pelayanan public menjadi terukur dan dapat dievaluasi keberhasilannya.

Selain kebijakan pemerintah, upaya mewujudkan kinerja pelayanan publik dilingkungan unit kerja pemerintahan yang terukur dan dapat dievaluasi keberhasilannya, pemerintah daerah perlu memiliki dan menerapkan Standar Operasional Prosedur (SOP).

Tujuan SOP sendiri adalah untuk menjelaskan rincian-rincian atau standar yang tetap mengenai aktifitas pekerjaan yang berulang-ulang yang diselenggarakann dalam hal ini adalah Dinas Penanaman Modal Pelayanan Terpadu Satu Pintu Kota Mataram. SOP yang baik tentunya harus mampu menjadikan arus kerja yang lebih baik dan maksimal juga dapat digunakan sebagai panduan atau pedoman serta dapat dijadikan sebagai alat yang bisa 
memudahkan dalam kegiatan pengawasan dalam hal ini SOP juga harus bisa memunculkan koordinasi yang baik antara bagian-bagian yang lain tetapi tetap dalam satu kantor pelayanan

Tujuan Standar Operasional Prosedur (SOP) adalah sebagai.

1. Untuk menjaga konsistensi tingkat penampilan kinerja atau kondisi tertentu dan kemana petugas dan lingkungan dalam melaksanakan sesuatu tugas atau pekerjaan tertentu;

2. Sebagai acuan dalam pelaksanaan kegiatan tertentu bagi sesama pekerja, dan supervisor;

3. Untuk menghindari kegagalan atau kesalahan (dengan demikian menghindari dan mengurangi konflik), keraguan, duplikasi serta pemborosan dalam proses pelaksanaan kegiatan;

4. Merupakan parameter untuk menilai mutu pelayanan;

5. Untuk lebih menjamin penggunaan tenaga dan sumber daya secara efisien dan efektif;

6. Untuk menjelaskan alur tugas, wewenang dan tanggung jawab dari petugas yang terkait;

7. Sebagai dokumen yang akan menjelaskan dan menilai pelaksanaan proses kerja bila terjadi suatu kesalahan atau dugaan mal praktek dan kesalahan administratif lainnya, sehingga sifatnya melindungi rumah sakit dan petugas;

8. Sebagai dokumen yang digunakan untuk pelatihan;

9. Sebagai dokumen sejarah bila telah di buat revisi SOP yang baru.
Manfaat SOP sendiri adalah untuk penetapan tertulis mengenai apa yang harus dikerjakan dan dijalankan kapan dimana dan oleh siapa dibuat dengan tujuan untuk menghindari terjadinya perbedaanperbedaan dalam kegiatan proses pelaksanaan pelayanan perizinan yang dilakukan oleh pegawai yang akan dapat mengganggu kinerja.

Sebagai salah satu strategi untuk peningkatan pelayanan publik dengan menciptakan kebijakan yang mendukung terselenggaranya pelayanan publik yang efektif dan efisien dari segi waktu dan segi biaya. Untuk mempercepat proses perizinan dalam rangka kegiatan pelayanan publik bagi masyarakat tentunya hal ini dengan adanya SOP juga bertujuan untuk memberikan kepastian hukum pada masyarakat karena akibat adanya standar pelayanan tersebut terdapat transparansi dan akuntabilitas kepada masyarakat. Sehingga dengan kebijakan tersebut dapat menghindari perilaku yang menyimpang baik yang dilakukan oleh orang dalam ataupun orang luar yang mempunyai kepentingan yang kurang baik.

Standar Operasional Prosedur tentunya dalam hal ini di pakai oleh Dinas Penanaman Modal Pelayanan Terpadu satu Pintu Kota Mataram sebagai alat penilaian kinerja berorientasi pada penilaian kinerja internal kelembagaan, terutama dalam hal kejelasan proses kerja di lingkungan organisasi termasuk kejelasan unit kerja yang bertanggungjawab.

Tercapainya kelancaran kegiatan dan terwujudnya koordinasi, fasilitasi dan pengendalian yang meminimalisir tumpang tindih proses kegiatan di lingkungan subsub bagian dalam organisasi yang bersangkutan. Standar Operasional 
Prosedur berbeda dengan pengendalian program yang lebih diorientasikan pada penilaian pelaksanaan dan pencapaian outcome dari suatu program/kegiatan. Namun keduanya saling berkaitan karena Standar Operasional Prosedur merupakan acuan bagi Dinas Penanaman Modal dalam melaksanakan tugas dan kewajibannya termasuk dalam pelaksanaan kegiatan program.

Selama ini, penilaian akuntabilitas kinerja instansi pemerintah umumnya didasarkan pada standar eksternal padahal sebagai bentuk organisasi publik, instansi pemerintah memiliki karakteristik khusus yakni sifat birokratis dalam internal organisasinya. Hasil kajian menunjukkan tidak semua satuan unit kerja instansi pemerintah memiliki SOP, karena itu seharusnyalah setiap satuan unit kerja pelayanan publik instansi pemerintah memiliki standar operasional prosedur sebagai acuan dalam bertindak. Melalui penerapan SOP ini bertujuan untuk meningkatkan kinerja instansi pemerintah dan dapat dievaluasi dan terukur.

\section{PENUTUP}

Instansi Penyelenggara Pelayanan Publik Dinas Penanaman Modal Pelayanan Terpadu Satu Pintu Kota Mataram sudah memenuhi segala kriteria dan ketentuan persyaratan yang harus dipenuhi dalam penyelenggaraan sebuah pelayanan publik. Dinas Penanaman Modal Pelayanan Terpadu Satu Pintu Kota Mataram sebagi lembaga pemerintah yang mengeluarkan jenis-jenis izin usaha dan izin non usaha serta termasuk persyaratan dari izin-izin tersebut. Hal ini bertujuan untuk mengadakan kegiatan pengawasan dan pengendalian dan perlindungan di dalam kegiatan masyarakat untuk kepentingan umum dan juga dalam rangka meningkatkan kualitas penyelenggaraan pelayanan perizinan yang mengedepankan kesesuaian azas umum sebagai pemerintahan yang baik. Dinas Penanaman Modal Pelayanan Terpadu Satu Pintu Kota Mataram yang merupakan lembaga pelayanan publik yang melayani proses perizinan baik izin usaha dan non usaha dalam melakukan kegiatan pelayanan perizinan tentunya menemui hambatanhambatan dalam proses pelayanan yang dilakukan diantaranya adalah hambatan diantaranya Adanya tim koordinasi yang dianggap menghambat proses perizinan oleh para pelaku usaha di Kota Mataram., Adanya calo izin dan pungutan liar di Dinas Penanaman Modal Pelayanan Terpadu Satu Pintu Kota Mataram yang membuat pengurusan izin dirasakan berbelit dan mahal oleh para pelaku usaha di Kota Mataram., Adanya keterbatasan fasilitas kerja yang kurang memadai membuat proses pelaksanaan pelayanan menjadi terhambat. Adanya promosi jabatan dan mutasi pegawai yang masih mengunakan patronage system (kekerabatan) yang membuat segala sesuatu menjadi lebih baik dan tidak membuat pelayanan perizinan menjadi lebih baik. Salah satu upaya yang di lakukan oleh Dinas Penanaman Modal Pelayanan Terpadu Satu Pintu Kota Mataram dalam melakukan kegiatan pelayanan perizinan guna menarik simpati masyarakat dan guna menyadarkan masyarakat atas kepentingan legalitas usahanya dan juga dalam rangka melakukan pelayanan perizinan yang baik ada beberapa upaya yang dilakukan oleh Dinas Penanaman Modal Pelayanan Terpadu Satu Pintu Kota Mataram 
diantaranya adalah Izin Sehati (sehari pasti jadi), izin paket pelayanan perizinan dimana izin bisa dilakukan secara simultan, menciptakan Standar Operasional Pelayanan yang berfungsi juga sebagai ukuran tercapainya kelancaran kegiatan dan terwujudnya koordinasi.

\section{DAFTAR PUSTAKA}

\section{Buku}

Adrian Sutedi, Hukum Perizinan Dalam Sektor Pelayanan Publik, Cetakan Ketiga, Jakarta: Sinar Grafika, 2015.

Ermanto Fahamsyah, Hukum Penanaman Modal, Pengaturan, Pembatasan, Pengaruh Budaya Hukum dan Praktik Penanaman Modal Indonesia, Yogyakarta: Laksbang PRESSindo, 2015.

Hartatik dan Indah Puji, Buku Praktis Pengembangan Sumber Darya Manusia, Yogyakarta: Laksana, 2014.

Lijan Poltak Sinambela, Reformasi Pelayanan Publik: Teori, Kebijakan dan Implermentasi, Jakarta: Sinar Grafika Offset, 2008.

Salim HS dan Erlies Septiana Nurbani, Penerapan Teori Hukum Pada Penelitian Tesis dan Desertasi, Jakarta: Raja Grafindo Persada, 2014.

Tabrani Rusyan, Pendekatan dalam Proses Belajar Mengajar, Bandung: Remaja Rosdakarya, 2009.

Utrecht, E, Pengantar Dalam Hukum Indonesia, Jakarta: Ictiar, 1957.

\section{Jurnal}

Adhar Hakim., "Fungsi dan Peran Ombudsman Republik Indonesia Perwakilan Nusa Tenggara Barat Dalam Mendorong Kepatuhan Pemerintah Daerah Terhadap Undang-
Undang Nomor 25 tahun 2009 Tentang Pelayanan Publik", Jurnal IUS Fakultas

Hukum Universitas Mataram, Volume III, Edisi 7 April 2015.

Akhmad Marwi, "Kewenangan Penjabat

Kepala Daerah di Bidang Kepegawaian

Dalam Menyelenggarakan

Pemerintahan Daerah (Studi Pada

Pemerintahan Kota Mataram)", Jurnal IUS Universitas Mataram Volume IV, Edisi 3 Desember 2016.

Akib, Haedar dan Antonius Tarigan, "Artikulasi Konsep Implementasi

Kebijakan: Perspektif, Model dan Kriteria Pengukuranya", Jurnal Baca, Volume 1 Agustus 2008, Universitas Pepabri Makasar.

Arba, L. Sayafrudin, Diangsa Wagian, "Kajian Normatif Perencanaan Penataan Ruang dan Penatagunaan Tanah", Jurnal Hukum Jatiswara, Fakultas Hukum, Universitas Mataram, Vol. 30, No. 1, Maret, 2015.

Hardijan Rusli, "Metode Penelitian Hukum Normatif', Law Review, Fakultas Hukum Universitas Pelita Harapan, 2006.

Sarkawi, "Pedoman, Bentuk dan Teknik Pelaksanaan Fungsi Pengawasan DPRD”, Jurnal Hukum Jatiswara, Fakultas Hukum Universitas Mataram, Vol. 30, No, 1, Maret 2015.

\section{Rujukan Internet}

http://www.suduthukum.com/2017/07/pen gertian-calo.html. 